\title{
- Bioprospecting and Therapeutic Applications of Cocos nucifera L. Sprouts
}

\section{IJCRR}

Section: Healthcare

ISI Impact Factor

(2019-20): 1.628

IC Value (2019): 90.81

$\operatorname{SJIF}(2020)=7.893$

(c) (7) (8)

Copyright@IJCRR

\section{S. Abiraami Valli ${ }^{1}$, S. Uma Gowrie ${ }^{2 *}$}

'Research Scholar, Department of Plant Biology and Plant Biotechnology, Ethiraj College for Women (Autonomous), Affiliated to the University of Madras, Chennai- 6oo oo8, Tamil Nadu, India; 'Associate Professor and Dean of Research (Aided), Department of Plant Biology and Plant Biotechnology, Ethiraj College for Women (Autonomous), Affiliated to the University of Madras, Chennai- 600 oo8, Tamil Nadu, India.

\section{ABSTRACT}

Introduction: Cocos nucifera L. is known for all its multiple utilities especially for its nutritional value. The Coconut's basal part of the embryo enlarges to form sprout/haustorium.

Aim: The objective is to compare the phytoconstituents and its bioefficacy of the coconut meat (cellular endosperm) and its sprouts (haustorium) using bioassays leading to novel drug development recommending for the development of nutraceuticals.

Methodology: Studies on toxicity, shelf-life of the dried powdered samples were carried out. Quantification of total lipids, flavonoids, vitamin- $\mathrm{C}$, determination of amylase activity was performed using methanol and aqueous extracts. Bioassays such as antibacterial, in vitro antioxidant and anti-inflammatory assays, were conducted. Phytoconstituents were characterized by GC-MS. The cytotoxic effect of the samples was analyzed in human gastric adenocarcinoma epithelial (AGS) cell line infected with gastric ulcer.

Results: Toxicity and shelf-life studies had indicated that the samples were non-toxic with the shelf-life extending up to 180 days. Quantitative analysis showed maximum flavonoids followed by vitamin- $C$ with reduced levels of lipids in the coconut sprouts when compared to coconut meat. Promising amylase activity was revealed by coconut sprouts as these had the potency to decrease the concentration of starch substrate. Prominent zone of inhibitions in the antibacterial assay was recorded in the samples assayed. In vitro, antioxidant assays and anti-lipoxygenase activity signified the enriched bioactive potential of the coconut sprouts. GC-MS analysis had revealed variations in the presence of primary and secondary metabolites. Coconut sprouts extracts were found to be cytotoxic to the infected cells.

Conclusion: Coconut sprouts can be recommended as an economically potent natural product for the commercial production of nutraceuticals in the food industry further to be used as a nutrient supplement in the prevention and management of peptic ulcers with a cost-effective approach.

Key Words: Coconut sprouts, Coconut meat, Phytoconstituents, Phytochemical characterization, Cell line, Nutraceuticals

\section{INTRODUCTION}

Coconut (Cocos nucifera L.) belonging to Arecaceae is well known for all its utilities. India is the $3^{\text {rd }}$ largest coconut producer where, Tamil Nadu, Kerala, Andhra Pradesh and Karnataka is said to produce 90 per cent of the coconut production. Coconut products are used in daily life by different classes of people. These are some of the prominent sources for the development of medicines and industrial products. Coconut and its products are used as folk medicine and therefore, the coconut palm in Indian classics is known as 'Kalpavriksha'.'
After the germination of the coconut, the embryo (basal part) usually enlarges and produce sprout/haustorium and its cardioprotective effect was evaluated. ${ }^{2}$ Coconut sprouts wine was produced using Saccharomyces cerevisiae which was found to be enriched with antioxidant activity. ${ }^{3}$ Primary and secondary phytoconstituents derived from natural products have gained attention for the prevention and management of several diseases. The presence of squalene, a potent triterpenoid with anti-ulcer activity in the sprouts of Cocos nucifera L. was confirmed through in silico molecular docking. ${ }^{4}$

\section{Corresponding Author:}

Dr. S. Uma Gowrie, Associate Professor and Dean of Research (Aided), Department of Plant Biology and Plant Biotechnology, Ethiraj College for Women (Autonomous), Affiliated to the University of Madras, Chennai - 600 008, Tamil Nadu, India; Email: umasezhian@gmail.com

ISSN: 2231-2196 (Print)

Received: 13.02 .2021
ISSN: 0975-5241 (Online)

Revised: 17.04 .2021
Accepted: 02.07 .2021 
Peptic ulcer occurs in the entire gastrointestinal tract. Gastric ulcers are produced when there is an imbalance between toxic and cytoprotective factors. Toxic endogenous factors include leukotrienes, pepsin, refluxed bile, hydrochloric acid and reactive oxygen species. Toxic exogenous factors include Helicobacter pylori, ulcer-causing gram-negative bacterial strains, steroidal as well as non-steroidal antiinflammatory drugs (NSAIDs), alcohol which initiates the secretion of gastric acid and pepsin. ${ }^{5}$ Cytoprotective factors include prostaglandins, surface-active phospholipids, cell renewal followed by its migration, mucosal blood flow, enzymatic and non-enzymatic antioxidants and mucus-bicarbonate barrier. In recent years, the peptic ulcer has become a major challenge affecting many people. Recent advancements in gastric ulcer therapy aim to suppress the production of gastric acid through the use of antacids, $\mathrm{H}_{2}$-receptor inhibitors/blockers which include famotidine, ranitidine and several anticholinergics especially telezipine and pirenzepine or sometimes proton-pump inhibitors/blockers such as lansoprazole and omeprazole. However, the major drawback in these advances in modern medicine is the major side effects with limited bioefficacy caused by these drugs. ${ }^{6}$ Thus, in the present scenario, there is a need for prevention and management of peptic ulcers especially gastric ulcers using plant-derived natural products.

Coconut sprouts is a great boon to the food and pharmaceutical industries for the development of nutrient supplements and novel drugs for managing peptic ulcer. Since not much work has been carried out in Cocos nucifera L. sprouts, the objective and purpose of the present study are to compare the phytoconstituents and its bioefficacy of the coconut meat and its sprouts using various bioassays leading to novel drug development recommending for the development of nutraceuticals.

\section{MATERIALS AND METHODS}

\section{Sample collection}

Mature coconut (Cocos nucifera L.) and its sprouts (haustorium) were procured from Thirunelveli District, Tamil Nadu, India and were processed by shade dry method. ${ }^{7}$ (Figure 1).

\section{Toxicity analysis}

Dried powdered samples were analyzed for the presence of toxic heavy metals such as arsenic, cadmium, cobalt, chromium, mercury, nickel and lead using Inductively Coupled Plasma Optical Emission Spectrometry. ${ }^{8}$

\section{Shelf-life study}

Dried powder of the samples collected during the initial period of the study, after $3^{\text {rd }}$ month and $6^{\text {th }}$ month were screened for microbial content using serial dilution technique. Dilutions of
$10^{-6}, 10^{-7}, 10^{-8}$ and $10^{-9}$ for total bacterial count and dilutions of $10^{-2}, 10^{-3}, 10^{-4}$ and $10^{-5}$ for total fungal count were used to test the microbial quality. ${ }^{9}$

\section{Extraction and Quantificationstudies}

Dried powdered samples were extracted with butanol, acetone, chloroform, methanol, aqueous w/v (1:10) using the cold percolation method. ${ }^{7}$ Based on qualitative phytochemical studies ${ }^{4}$, methanol and aqueous extracts were taken for the present study. For the documentation of results, sample extracts were abbreviated as, coconut meat extracted with methanol (CCM), aqueous (CCAq); coconut sprouts extracted with methanol (CSM), aqueous (CSAq). Lipids ${ }^{10}$, flavonoids ${ }^{11}$ and vitamin- $\mathrm{C}^{12}$ were quantified and amylase activity was assayed. ${ }^{13}$

\section{Antibacterial assay}

Sample extracts of 20,40, 60and $80 \mu \mathrm{g} \mathrm{mL}^{-1}$ were assayed against Bacillus subtilis, Staphylococcus epidermidis, Escherichia coli and Pseudomonas aeruginosa using agar well diffusion method. ${ }^{4}$

\section{In vitro bioassays}

In vitro antioxidant assays [assessment of metal chelating activity, ${ }^{14}$ 2,2'-Azino-bis(3-ethylbenzthiazoline-6-sulphonic acid) $\mathrm{ABTS}^{+}$assay $]^{15}$ and assessment of anti-lipoxygenase activity $^{16}$ (anti-inflammatory assay) was conducted.

\section{Gas Chromatography-Mass Spectrometry (GC-}

\section{MS) analysis}

GC-MS analysis ${ }^{17}$ of methanol extracts of the samples were conducted at Sophisticated Analytical Instrument Facility (SAIF), IIT Madras, Chennai, Tamil Nadu, India.

\section{3-(4,5-dimethylthiazol-2-yl)-2,5-diphenyl tetrazo- lium bromide (MTT) assay}

Human gastric adenocarcinoma (AGS) epithelial cell line with mucus-secreting epithelial cells was obtained from National Centre for Cell Science (NCCS), Pune, India. Indomethacin, an NSAID was used as a gastric ulcer causing agent. Cimetidine, an anti-ulcer drug was used as standard. MTT assay using sample extracts were performed. ${ }^{7}$

\section{Statistical analysis}

For each experiment, the data presented are the means of three replicates. Values are expressed as mean $\pm \mathrm{SE}$.

\section{RESULTS}

\section{Toxicity analysis}

Heavy metals (As, Cd, Co, $\mathrm{Cr}, \mathrm{Hg}, \mathrm{Ni}, \mathrm{Pb}$ ) were found to be below the detectable limit (BDL) in the samples. 


\section{Shelf-life study}

The study revealed nil growth of pathogenic bacteria and fungi at different dilutions used thereby indicating that the dried powdered samples (initial period of the study, after $3^{\text {rd }}$ and $6^{\text {th }}$ month) were found to be sterile and free from the microbial load with good shelf-life extending up to 180 days (Figure 2).

\section{Quantificationstudies and determination of amylase activity}

Total flavonoid content was reported as Quercetin equivalent, standard curve $\left(0.0097 x+0.1349 ; \mathrm{R}^{2}=0.9981\right)$. Methanol and aqueous coconut sprouts extracts had maximum flavonoids $\left(83.89 \pm 0.07\right.$ and $82.37 \pm 0.19 \mathrm{mg}$ of $\left.\mathrm{QE} \mathrm{g}^{-1}\right)$ whereas coconut meat extracts had $62.25 \pm 0.20$ and $61.38 \pm 0.23 \mathrm{mg}$ of $\mathrm{QE} \mathrm{g}^{-1}$ of flavonoids. Vitamin- $\mathrm{C}$ was calculated from ascorbic acid standard curve $\left(0.0096 x+0.0427 ; R^{2}=0.9986\right)$. Methanol and aqueous coconut sprouts extracts had maximum vitamin- $\mathrm{C}$ $\left(0.74 \pm 0.02\right.$ and $\left.0.73 \pm 0.02 \mathrm{mg} \mathrm{g}^{-1}\right)$ whereas, coconut meat extracts had $0.38 \pm 0.03$ and $0.37 \pm 0.02 \mathrm{mg} \mathrm{g}^{-1}$ of vitamin- C. Total lipids were calculated from cholesterol standard curve $\left(0.0098 x+0.041 ; \mathrm{R}^{2}=0.9966\right)$. Methanol and aqueous coconut sprouts extracts had reduced levels of lipids $(0.21 \pm 0.02$ and $0.25 \pm 0.02 \mathrm{mg} \mathrm{g}^{-1}$ ) whereas, coconut meat extracts had $0.71 \pm 0.04$ and $0.78 \pm 0.03 \mathrm{mg} \mathrm{g}^{-1}$ of total lipids (Figure 3).

Amylase activity monitored over 60 minutes period at 15 minutes interval, indicated that the concentration of substrate decreased with the time reducing from $18.2 \pm 0.21$ to $2.4 \pm$ $0.12 \mu \mathrm{g} \mathrm{mL}-1$ and $19.1 \pm 0.22$ to $2.8 \pm 0.11 \mu \mathrm{g} \mathrm{mL} \mathrm{m}^{-1}$ in methanol and aqueous coconut sprout extracts when compared to the coconut meat extracts $\left(20.3 \pm 0.22\right.$ to $3.1 \pm 0.13 \mu \mathrm{g} \mathrm{mL}^{-1}$ and $21.7 \pm 0.23$ to $4.3 \pm 0.15 \mu \mathrm{g} \mathrm{mL}^{-1}$ in 60 minutes). It was observed that there were no marked variations between the extracts whereas remarkable variations were found between the coconut meat and its sprouts indicating that the sprouts are rich in phytoconstituents.

\section{Antibacterial assay}

Methanol and aqueous coconut sprouts extracts indicated a maximum zone of inhibitions of $35.66 \pm 0.27 \mathrm{~mm}$ and 35.37 $\pm 0.29 \mathrm{~mm}$ at $80 \mu \mathrm{g} \mathrm{mL}^{-1}$ against Staphylococcus epidermidis and maximum zone of inhibitions of $34.89 \pm 0.27 \mathrm{~mm}$ and $34.78 \pm 0.25 \mathrm{~mm}$ at $80 \mu \mathrm{g} \mathrm{mL}^{-1}$ against $P$ seudomonas aeruginosa. Coconut meat extracts indicated a zone of inhibitions $(28.59 \pm 0.28 \mathrm{~mm}$ and $27.93 \pm 0.23 \mathrm{~mm})$ against Staphylococcus epidermidis. Remarkable variations were observed among the sample extracts (Figure 4).

\section{In vitro bioassays}

The antioxidant and anti-inflammatory potential of the sample extracts were determined based on the $\mathrm{IC}_{50} .100 \mu \mathrm{g} \mathrm{mL}^{-1}$ showed maximum bioactivities. In metal chelating activity, methanol and aqueous coconut sprouts extracts showed maximum per cent inhibition $(85.22 \pm 0.26$ and $84.75 \pm 0.28)$ with $\mathrm{IC}_{50}$ values, 33.01 and $35.13 \mu \mathrm{g} \mathrm{mL}^{-1}$. Methanol and aqueous coconut meat extracts revealed per cent inhibition of $54.57 \pm 0.29$ and $53.27 \pm 0.27$ with $\mathrm{IC}_{50}$ values, 87.72 and $90.35 \mu \mathrm{g} \mathrm{mL}^{-1}$. Na ${ }_{2}$ EDTAindicated $86.24 \pm 0.26$ per cent inhibition with $\mathrm{IC}_{50}$ value, $31.0 \mu \mathrm{g} \mathrm{mL}^{-1}$. $\mathrm{ABTS}^{+}$assay revealed that methanol and aqueous coconut sprouts extracts showed maximum per cent inhibition ( $88.39 \pm 0.27$ and $87.32 \pm 0.27)$ with $\mathrm{IC}_{50}$ values, 31.29 and $32.96 \mu \mathrm{g} \mathrm{mL}^{-1}$. Methanol and aqueous coconut meat extracts revealed per cent inhibition of $52.66 \pm 0.27$ and $51.54 \pm 0.29$ with IC $_{50}$ values, 96.67 and $99.88 \mu \mathrm{g} \mathrm{mL}^{-1}$. Ascorbic acid indicated $90.34 \pm 0.26$ per cent inhibition with $\mathrm{IC}_{50}$ value, $28.68 \mu \mathrm{g} \mathrm{mL}^{-1}$.

Concerning anti-inflammatory assay, methanol and aqueous coconut sprouts extracts showed maximum per cent inhibition $(92.27 \pm 0.25$ and $91.78 \pm 0.24)$ with $\mathrm{IC}_{50}$ values, 26.66 and $27.90 \mu \mathrm{g} \mathrm{mL}^{-1}$. Methanol and aqueous coconut meat extracts revealed per cent inhibition of $62.97 \pm 0.23$ and 61.88 \pm 0.21 with $\mathrm{IC}_{50}$ values, 68.69 and $71.07 \mu \mathrm{g} \mathrm{mL}^{-1}$. Indomethacin indicated $94.46 \pm 0.27$ per cent inhibition with $\mathrm{IC}_{50}$ value, $21.85 \mu \mathrm{g} \mathrm{mL}^{-1}$. There were marked variations between the coconut meat and its sprouts, in which the sprout extracts had maximum antioxidant and anti-inflammatory activity on par with standard (Figure 5).

\section{Gas Chromatography-Mass Spectrometry (GC- MS) analysis}

Various peaks were observed in coconut sprouts extract representing the volatile compounds of the phytoconstituents such as flavonoids, terpenoids, phenols, proteins, amino acids, carbohydrates, vitamins, essential fatty acid esters when compared to the coconut meat which had phenols, alkaloids, fatty acid esters (Figure 6). 3',4',5,7-Tetrahydroxyflavone was found to be abundantly present in coconut sprouts with a peak area per cent of 88.2 (Table $1 \&$ Table 2).

\section{MTT assay}

Methanol and aqueous coconut sprouts extracts $(100 \mu \mathrm{g} \mathrm{mL}$ 1) showed maximum per cent inhibition of infected AGS cells $(93.92 \pm 0.23$ and $92.12 \pm 0.27)$ with $\mathrm{IC}_{50}$ values, 20.23 and $22.11 \mu \mathrm{g} \mathrm{mL}^{-1}$. Methanol and aqueous coconut meat extracts revealed a per cent inhibition of $67.11 \pm 0.25$ and 66.12 \pm 0.26 with $\mathrm{IC}_{50}$ values, 67.66 and $68.98 \mu \mathrm{g} \mathrm{mL}^{-1}$. Cimetidine $\left(100 \mu \mathrm{g} \mathrm{mL}^{-1}\right)$ indicated $94.85 \pm 0.29$ per cent inhibition with $\mathrm{IC}_{50}$ value, $18.83 \mu \mathrm{g} \mathrm{mL}^{-1}$. Methanol and aqueous extracts of the coconut sprouts were found to be cytotoxic to the infected AGS cells with gastric ulcers in a dose-dependent manner when compared to the coconut meat extracts (Figure 7). An increase in the concentration of sample extracts has increased the cytotoxic activity of the samples. There was a remarkable variation between the samples in which coconut sprouts extracts had maximum anti-ulcer activity on par with the standard. 


\section{DISCUSSION}

Bioprospecting of natural plant-derived food products leads to the study of phytoconstituents and the identification of novel compounds with pharmaceutical properties.

Plant and plant-derived food products may be contaminated with toxic heavy metals or other residues resulting in health issues. Lead, cadmium, mercury, chromium in the food products cause gastric ulcer/cancer through the disruption of the gastric mucosa. These heavy metals along with arsenic were reported to be exogenous sources of ROS resulting in gastric mucosal tissue damage, epithelial, endothelial inflammation, where, cadmium affect E-cadherin function. Cobalt induces DNA damage, nickel modify the activity of catalase through ROS generation causing gastric ulcer/cancer. ${ }^{18}$ Hence, it is essential to analyze the toxicity of the samples. ICP-OES analysis was applied to metal concentrations in the samples. Present findings are clear evidence that the samples were found to be non-toxic and can be recommended for consumption as a natural edible product for the prevention and management of several diseases.

During germination, moisture content, nutrients released and the warm appropriate temperature are favourable for the growth of pathogens. Analyzing the microbiological quality of the samples signifies the importance of the study. The present study proves that the dried powdered samples were found to be pure and free from the microbial load with shelflife extending up to 180 days. This reveals that the samples were found to be from a clean environment which can be best used for the preparation of nutraceuticals.

Flavonoids are potent bioactive compounds with a polyphenolic structure occurring in various natural edible plant-derived food products with health-promoting benefits having nutraceutical and pharmaceutical applications. These tend to possess biochemical, antioxidant, anti-inflammatory, anticancer activities due to which the use of flavonoids in the commercial production of nutraceutical and pharmaceutical drugs are in increasing demand. Several reports have indicated that flavonoids possess gastroprotective, cytoprotective and anti-secretory activities. ${ }^{19}$ Ascorbic acid or vitamin$\mathrm{C}$, a water-soluble vitamin is responsible for reducing the bleeding in gastric ulcers, in addition to the reduction of the NSAIDs related gastric mucosal destructions or damage and Helicobacter pylori suppression. Lipids include fats, phospholipids, sterols and glycolipids which are almost found in all living cells. Glycolipids are found in edible parts of the plant. Increased lipid content may lead to gastric ulcers and carcinomas. The present finding is scientifically validated that the coconut sprouts are enriched bioactive compounds and reduced level of lipids than the coconut meat. Thus, coconut sprouts are an alternative source of coconut meat with high cholesterol. It has solved the issue as a natural edible product found to be enriched with potent phytoconstituents used in the prevention and management of ulcers and other diseases with no side effects. Elevated levels of amylase can cause acute gastritis. Amylase activity in the coconut sprouts was found to be at a permissible level and it helps in the breakdown of complex substances. Hence, it is considered safe for different age groups of people to consume coconut sprouts.

Developing resistance breaking natural antimicrobial agents are the need of the hour in the present scenario. Current findings prove that when compared to the coconut meat, the coconut sprouts with the prominent shelf-life period, enriched flavonoids, ascorbic acid act as a natural antibacterial agent. Bioactive flavonoids act against the pathogenic bacteria by inhibiting the synthesis of nucleic acids, functions of the cytoplasmic membrane, energy metabolism resulting in potent antibacterial activity. ${ }^{20}$

In the metal chelating assay, ferrozine chelate with $\mathrm{Fe}_{2}{ }^{+}$and form a complex. ROS induce gastric mucosal damage. ${ }^{21} \mathrm{An}-$ tioxidants in the sample extracts form a coordinate complex with metal ions, inhibit electron transfer and no free radicals are produced. Suppression of $\mathrm{ABTS}^{+}$ions is essential to reduce the release of free radicals resulting in healthy tissue damage. Flavonoids and essential phytoconstituents in the coconut sprouts might be responsible for this antioxidant activity. The present study has proved that when compared to coconut meat extracts, the coconut sprouts had a maximum antioxidant activity with minimal $\mathrm{IC}_{50}$ value.

The inflammatory process involves the activity of inflammatory mediators (ROS, nitric oxide, neutrophil-derived free radicals, cytokines and prostaglandins). Increased levels of these mediators lead to injury of the tissues by damaging the macromolecules, lipid peroxidation of the membrane. Lipoxygenases contain non-heme iron dioxygenases mostly involved in leukotrienes synthesis which are essential for inflammation and hence these are the most promising inflammatory target. ${ }^{22}$ Present findings have proved that the antilipoxygenase activity was found to be in maximum in the coconut sprouts than the coconut meat which indicated that the sprouts are natural bioactive anti-inflammatory agents enriched with essential flavonoids.

In GC-MS analysis, coconut sprouts have maximum flavonoids constituting flavanones, flavonols, flavones, anthocyanidins and isoflavones indicating a promising role in preventing/healing peptic ulcers leading to a cytoprotective shield in the gastrointestinal region. It can be an alternative for the reduction of peptic ulcers associated with Helicobacter pylori infection/NSAIDs ${ }^{7}$ thereby contributing therapeutic biological effects.

Human gastric adenocarcinoma (AGS) cell line with mucussecreting epithelial cells used as an in vitro model is an appropriate cell line related to peptic ulcers/gastric cancers. 
Indomethacin (NSAID) is considered an instant gastric ulcer-causing agent which inhibits the synthesis of prostaglandins and thereby causes gastric ulcers. Prostaglandins are protective factors that prevent mucosal damage. Cimetidine, a modern commercial anti-ulcer drug heals gastric ulcers. Decreasing absorbance in the cells treated with the methanol and aqueous extracts of the coconut sprouts suggests cytotoxicity to AGS infected cells with gastric ulcers. MTT assay proved that the coconut sprouts were found to be cytotoxic to the infected AGS cell line with a gastric ulcer in a dosedependent manner. The minimum $\mathrm{IC}_{50}$ value of the coconut sprouts extracts has indicated that the sprouts are possessing promising bioactive potential due to enriched phytoconstituents which are involved in various metabolic pathways leading to the inhibition of ulcers.

Significant findings and novelty of the present study include (i) First report of bioprospecting study of sprouts of Cocos nucifera $\mathrm{L}$. (haustorium) revealing potent anti-ulcer activity through in vitro analysis using AGS cell line; (ii) Presence of flavonoids proves that coconut sprouts can be recommended as a natural edible product; (iii) Commercial production of nutraceuticals for the prevention and management of peptic ulcers; (iv) Presence of specific secondary metabolites in coconut sprouts are found to be advantageous over coconut meat; (v) Hesitation in consumption of coconut meat due to its rich cholesterol and lipid content finds the consumption of coconut sprouts with less cholesterol as an alternative source.

\section{CONCLUSION}

A bioprospecting study revealed that the coconut sprouts are enriched with maximum flavonoids, vitamin- $\mathrm{C}$ and permissible amylase activity with minimum lipids when compared to the coconut meat. Cocos nucifera $\mathrm{L}$. sprouts possess promising antibacterial, antioxidant and anti-inflammatory activities. GC-MS and MTT assay indicated the presence of essential bioactive compounds responsible for the cytotoxic activity of the sprouts against the AGS cell line with gastric ulcer. Thus, coconut sprouts can be recommended as an economically potent natural product for the commercial production of nutraceuticals in the food industry. Further, it can be used as a nutrient supplement in the prevention and management of gastric ulcers with a cost-effective approach as well can be recommended to the pharmaceutical industries for novel drug development and drug discovery.

\section{Conflicts of Interests: None.}

\section{Source of Funding}

Our sincere thanks to the Directorate of Collegiate Education, Department of Higher Education, Government of Tamil Nadu, India for the PhD. Merit Scholarship and Ethiraj Centre for
Research, Innovation \& Creativity (ECRIC), Ethiraj College for Women (Autonomous), Chennai for the PhD. Research fellowship.

\section{ACKNOWLEDGEMENT}

The authors thank Principal \& Secretary, Ethiraj College for Women (Autonomous), ECRIC, Head, Former and Present, Faculty members, supporting staff of the Department of Plant Biology and Plant Biotechnology, Ethiraj College for Women, Chennai for their valuable support, encouragement throughout the entire period of research. We would also like to express our sincere thanks for the facilities extended by the Central Instrumentation Centre of Ethiraj College for Women and Sophisticated Analytical Instrument Facility (SAIF), IIT Madras, Chennai, Tamil Nadu, India.

\section{Author's Contribution}

S. Abiraami Valli performed the experiments, drafted the manuscript, analysed and interpreted the data.

Dr. S. Uma Gowrie, proposed the concept, designed the experiments, supervised, analysed, interpreted the data, technically supported, critically revised and finally approved the manuscript.

\section{REFERENCES}

1. DebMandal M, Mandal S. Coconut (Cocos nucifera L.: Arecaceae): In health promotion and disease prevention. Asian Pac J Trop Med. 2011;241-47.

2. Chikku AM, Rajamohan T. Dietary coconut sprout beneficially modulates cardiac damage induced by isoproterenol in rats. Bangladesh J Pharm. 2012; 7:258-65.

3. SreelekshmiMohan MR, Sayoojya KP, Souparnika AP, Sowparnika K, Pournami TS, Sabu KR, et al. Production of coconut sprout wine using Saccharomyces cerevisiae and its physicochemical analysis. MOJ Food Process Tech. 2018;6(5):445-49.

4. Valli SA, Gowrie SU. A study on the bioactive potential of fresh and dried sprouts of Cocos nucifera L.- An in vitro and in silico approach. Int J Pharm Pharm Sci. 2017;9(3):129-142.

5. Bandyopadhyay D, Biswas K, Bhattacharyya M, Reiter RJ and Banerjee RK. Gastric toxicity and mucosal ulceration induced by oxygen-derived reactive species, protection by melatonin. Current Mol Med. 2001;1(4):501-13.

6. Mota KSDL, Dias GEN, Pinto MEF, Luiz-Ferreira A, SouzaBrito ARM, Hiruma-Lima CA, et al. Flavonoids with Gastroprotective Activity. Molecules. 2009;14:979-1012.

7. Valli SA, Gowrie SU. Promising role of luteolin from the sprouts of Cocos nucifera L. in indomethacin-induced gastric ulcer of human gastric adenocarcinoma cell line. J Adv Sci Res. 2021;12(1-2):213-27.

8. Canbay HS, Doganturk M. Metals determination by microwave digestion ICP-OES of some dietary supplements and diet products in Turkey. Eurasian J Anal Chem. 2016;12(1):45-53.

9. Nagar V, Bandekar JR. Microbiological quality of packaged sprouts from supermarkets in Mumbai, India. Int J Food Safety, Nutri Public Health. 2009;2(2):165-75. 
10. Folch J, Lees M, Stanley GHS. A simple method for the isolation and purification of total lipids from animal tissues. J Biol Chem. 1957;226(1):497-509.

11. Adekola KA, Salleh AB, Zaidan UH, Azlan A, Chiavari E, Paciulli $\mathrm{M}$, et al. Total phenolic content, antioxidative and antidiabetic properties of coconut (Cocos nucifera L.) testa and selected bean seed coats. Ital J Food Sci. 2017;29:741-53.

12. Omaye ST, Turnbull JD, Sauberlich HE. Selected methods for the determination of ascorbic acid in animal cells, tissues and fluids. Methods Enzymol 1979;62:1-11.

13. Fatema F, Khan ZH, Khan ND, Mular SM. Determination of amylase activity from germinated Syzygium cumin seed (Jamun).Int. J. appl.2017;3(1):573-75.

14. Ebrahimzadeh MA, Pourmorad F, Bekhradnia AR. Iron chelating activity, phenol and flavonoid content of some medicinal plants from Iran. Afr J Biotech. 2008;7(18): 3188-92.

15. Okoh SO, Asekun OT, Familoni OB, Afolayan AJ. Antioxidant and free radical scavenging capacity of seed and shell essential oils extracted from Abrus precatorius (L). Antioxid. 2014;3:27887.
16. Leelaprakash G, Dass SM. In vitro anti-inflammatory activity of methanol extract of Enicostemma axillare. Int J Drug Dev Res. 2011;3(3):189-96.

17. Chathurdevi G, Gowrie SU. Potent bioactive metabolites of Casuarina junghuniana Miq. roots- A Therapeutic Approach. Int J Pharm Pharm Sci. 2017;9(3):158-65.

18. Yuan W, Yang N, Li X. Advances in understanding how heavy metal pollution triggers gastric cancer. BioMed Res Int 2016;110.

19. Panche AN, Diwan AD, Chandra SR. Flavonoids: an overview. J Nutr Sci 2016;5(e47):1-15.

20. Xie X, Yang W, Tang F, Chen X, Ren L. Antibacterial activities of flavonoids: structure-activity relationship and mechanism. Curr Med Chem 2015;22(1):132-49.

21. Repetto MG, Llesuy SF. Antioxidant properties of natural compounds used in popular medicine for gastric ulcers. Braz J Med Biol Res 2002;35(5):523-34.

22. Alisha, Dsouza MR, Sonia N. Pharmacognostical overview on Terminalia arjuna: A justification of folkloric belief. Int J Pharm Sci \& Res 2018;9(12):5411-23.

Table 1: GC-MS analysis of methanol extract of Cocos nucifera L. meat

\begin{tabular}{|c|c|c|c|c|c|c|}
\hline Compound Name & $\begin{array}{l}\text { Retention } \\
\text { time (mins) }\end{array}$ & $\begin{array}{l}\text { Molecular } \\
\text { formula }\end{array}$ & $\begin{array}{l}\text { Molecular } \\
\text { weight (g } \\
\left.\text { mol }^{-1}\right)\end{array}$ & $\begin{array}{l}\text { Peak } \\
\text { area } \%\end{array}$ & $\begin{array}{l}\text { Compound } \\
\text { nature }\end{array}$ & $\begin{array}{l}\text { Biological activities } \\
\text { (PubChem, NIST \& } \\
\text { ChEBI) }\end{array}$ \\
\hline Quinoline & 10.70 & $\mathrm{C}_{9} \mathrm{H}_{7} \mathrm{~N}$ & 129.16 & 66.34 & Alkaloid & Anti-malarial agent. \\
\hline $\begin{array}{l}\text { Methyl beta-D-galactopyr- } \\
\text { ranoside }\end{array}$ & 11.63 & $\mathrm{C}_{7} \mathrm{H}_{14} \mathrm{O}_{6}$ & 194.18 & $54 \cdot 33$ & Monosaccharide & Anti-tumor agent. \\
\hline $\begin{array}{l}\text { Dodecanoic acid, } \\
\text { 1-(Hydroxymethyl)-1,2- } \\
\text { Ethanediyl ester }\end{array}$ & 24.727 & $\mathrm{C}_{27} \mathrm{H}_{52} \mathrm{O}_{5}$ & 456.7 & $3 \cdot 39$ & Glyceryl diester & $\begin{array}{l}\text { Anti-ageing, anticancer } \\
\text { agent, lubricant. }\end{array}$ \\
\hline $\begin{array}{l}\text { Dodecanoic acid, 2-hy- } \\
\text { droxy-1-(hydroxymethyl) } \\
\text { ethyl ester }\end{array}$ & 27.003 & $\mathrm{C}_{15} \mathrm{H}_{30} \mathrm{O}_{4}$ & $274 \cdot 4$ & 65.0 & Dodecanoate ester & $\begin{array}{l}\text { Antiviral, antimicrobial, } \\
\text { emulsifying agent, emol- } \\
\text { lient. }\end{array}$ \\
\hline Glycerol Tricaprylate & 27.878 & $\mathrm{C}_{27} \mathrm{H}_{50} \mathrm{O}_{6}$ & 470.7 & $5 \cdot 59$ & Triglyceride & Anticonvulsant. \\
\hline Nonane, 1-Iodo- & 29.429 & $\mathrm{C}_{9} \mathrm{H}_{19} \mathrm{I}$ & 254.15 & 10.55 & Essential oil & Flavouring agent. \\
\hline $\begin{array}{l}\text { Dodecanoic acid, 1,2,3-Pro- } \\
\text { panetriyl ester }\end{array}$ & $29 \cdot 534$ & $\mathrm{C}_{39} \mathrm{H}_{74} \mathrm{O}_{6}$ & 639.0 & 8.80 & Glycerol derivative & Thickening agent. \\
\hline Tocopherols & 30.88 & $\mathrm{C}_{29} \mathrm{H}_{50} \mathrm{O}_{2}$ & 416.7 & $64 \cdot 72$ & Vitamin E & Antioxidant. \\
\hline Lauric anhydride & 31.705 & $\mathrm{C}_{24} \mathrm{H}_{46} \mathrm{O}_{3}$ & 382.6 & 68.33 & $\begin{array}{l}\text { Dodecanoic acid } \\
\text { derivative }\end{array}$ & $\begin{array}{l}\text { Antimicrobial, anti-ageing } \\
\text { agent. }\end{array}$ \\
\hline
\end{tabular}

Table 2: GC-MS analysis of methanol extract of Cocos nucifera L. sprouts

\begin{tabular}{|c|c|c|c|c|c|c|}
\hline Compound Name & $\begin{array}{l}\text { Reten- } \\
\text { tion time } \\
\text { (mins) }\end{array}$ & $\begin{array}{l}\text { Molecular } \\
\text { formula }\end{array}$ & $\begin{array}{l}\text { Molecular } \\
\text { weight (g } \\
\left.\text { mol }^{-1}\right)\end{array}$ & $\begin{array}{l}\text { Peak } \\
\text { area } \\
\%\end{array}$ & $\begin{array}{l}\text { Compound } \\
\text { nature }\end{array}$ & $\begin{array}{l}\text { Biological activities } \\
\text { (PubChem \& NIST) }\end{array}$ \\
\hline $\begin{array}{l}\text { 1,2,4-Triazine-5-thiol, } \\
\text { 3-amino-6-methyl- }\end{array}$ & 11.6 & $\mathrm{C}_{4} \mathrm{H}_{6} \mathrm{~N}_{4} \mathrm{~S}$ & 142.19 & 61.9 & Triazole & $\begin{array}{l}\text { Anticancer, anticonvulsant, anti- } \\
\text { inflammatory, anti-HIV, antituber- } \\
\text { cular agent. }\end{array}$ \\
\hline $\begin{array}{l}\text { Pent-1-yn-3-ene, 4-methyl- } \\
\text { 3-phenyl- }\end{array}$ & 14.08 & $\mathrm{C}_{12} \mathrm{H}_{12}$ & 156.22 & 8.1 & $\begin{array}{l}\text { Enyne deriva- } \\
\text { tive }\end{array}$ & $\begin{array}{l}\text { Anti-inflammatory, anticancer } \\
\text { agent. }\end{array}$ \\
\hline Flavone & 14.97 & $\mathrm{C}_{15} \mathrm{H}_{10} \mathrm{O}_{2}$ & 222.24 & $72 \cdot 3$ & Flavonoid & $\begin{array}{l}\text { Antimicrobial, antiviral, anti-in- } \\
\text { flammatory, antioxidant, antidiar- } \\
\text { rheal, anti-ulcer agent. }\end{array}$ \\
\hline Glucose & 15.82 & $\mathrm{C}_{6} \mathrm{H}_{12} \mathrm{O}_{6}$ & 180.16 & 3.4 & $\begin{array}{l}\text { Monosaccha- } \\
\text { ride }\end{array}$ & Energy source. \\
\hline
\end{tabular}


Table 1: (Continued)

\begin{tabular}{|c|c|c|c|c|c|c|}
\hline Compound Name & $\begin{array}{l}\text { Reten- } \\
\text { tion time } \\
\text { (mins) }\end{array}$ & $\begin{array}{l}\text { Molecular } \\
\text { formula }\end{array}$ & $\begin{array}{l}\text { Molecular } \\
\text { weight (g } \\
\left.\text { mol }^{-1}\right)\end{array}$ & $\begin{array}{l}\text { Peak } \\
\text { area } \\
\%\end{array}$ & $\begin{array}{l}\text { Compound } \\
\text { nature }\end{array}$ & $\begin{array}{l}\text { Biological activities } \\
\text { (PubChem \& NIST) }\end{array}$ \\
\hline $3^{\prime}, 4^{\prime}, 5,7$-Tetrahydroxyflavone & 16.87 & $\mathrm{C}_{15} \mathrm{H}_{10} \mathrm{O}_{6}$ & 286.24 & 88.2 & Flavonoid & $\begin{array}{l}\text { Exhibit antioxidant, anti-diabetic, } \\
\text { anti-inflammatory, antiviral, anti- } \\
\text { microbial, anticancer, anti-ulcer, } \\
\text { anti-allergic activities. }\end{array}$ \\
\hline $\begin{array}{l}\text { Carbamic acid, phenyl-, } \\
\text { phenylmethyl ester }\end{array}$ & $17 \cdot 47$ & $\mathrm{C}_{14} \mathrm{H}_{13} \mathrm{NO}_{2}$ & 227.26 & 44.8 & Phenol & Anti-tubercular agent. \\
\hline $\begin{array}{l}\text { Quinoxaline, 2-isopropyl- } \\
\text { 3-phenyl-, 4-oxide }\end{array}$ & 18.45 & $\mathrm{C}_{17} \mathrm{H}_{16} \mathrm{~N}_{2} \mathrm{O}$ & 264.32 & 54.2 & Quinoxaline & $\begin{array}{l}\text { Possess anti-tubercular, antiviral, } \\
\text { anti-protozoan, anti-parasitic, } \\
\text { anti-inflammatory, anti-diabetic } \\
\text { activities. }\end{array}$ \\
\hline Ascorbic acid & 18.45 & $\mathrm{C}_{6} \mathrm{H}_{8} \mathrm{O}_{6}$ & 176.12 & $69 \cdot 3$ & Vitamin-C & Antioxidant, detoxicant. \\
\hline $\begin{array}{l}\text { 16-Octadecenoic acid, me- } \\
\text { thyl ester }\end{array}$ & 19.2 & $\mathrm{C}_{19} \mathrm{H}_{36} \mathrm{O}_{2}$ & 296.49 & $47 \cdot 4$ & Methyl ester & $\begin{array}{l}\text { Exhibit cancer preventive, anti- } \\
\text { inflammatory, anti-androgenic, } \\
\text { dermatitigenic, properties. }\end{array}$ \\
\hline $\begin{array}{l}\text { Pyrimidine, 5-ethyl-2-[4-(4- } \\
\text { ethylcyclohexyl)-phenyl]- }\end{array}$ & 19.88 & $\mathrm{C}_{20} \mathrm{H}_{26} \mathrm{~N}_{2}$ & 294.4 & 14.0 & $\begin{array}{l}\text { Pyrimidine } \\
\text { group }\end{array}$ & $\begin{array}{l}\text { Anti-inflammatory, antiviral, an- } \\
\text { tipyretic, antioxidant, anticonvul- } \\
\text { sant, analgesic, antihypertensive, } \\
\text { anti-diabetic, anticancer agent. }\end{array}$ \\
\hline Squalene & 21.08 & $\mathrm{C}_{30} \mathrm{H}_{50}$ & 410.7 & 68.5 & Triterpenoid & $\begin{array}{l}\text { Anticancer, anti-inflammatory } \\
\text { agent. }\end{array}$ \\
\hline $\begin{array}{l}\text { Phenol, 2,6-bis(1,1- } \\
\text { dimethylethyl)-4-[(4-hy- } \\
\text { droxy-3,5-dimethylphenyl }) \\
\text { methyl]- }\end{array}$ & 22.45 & $\mathrm{C}_{23} \mathrm{H}_{32} \mathrm{O}_{2}$ & 340.5 & 51.4 & Polyphenol & Antioxidant. \\
\hline $\begin{array}{l}\text { 3,4-Dihydroxy-1,6-bis-(3- } \\
\text { methoxy-phenyl)-hexa-2,4- } \\
\text { diene-1,6-dione }\end{array}$ & 24.23 & $\mathrm{C}_{20} \mathrm{H}_{18} \mathrm{O}_{6}$ & $354 \cdot 4$ & $64 \cdot 7$ & $\begin{array}{l}\text { Diarylhepta- } \\
\text { noid }\end{array}$ & $\begin{array}{l}\text { Hepato-protective, anti-cathartic, } \\
\text { anti-ulcer, anti-diabetic, diuretic, } \\
\text { anti-neoplastic agent and lowers } \\
\text { cholesterol. }\end{array}$ \\
\hline
\end{tabular}

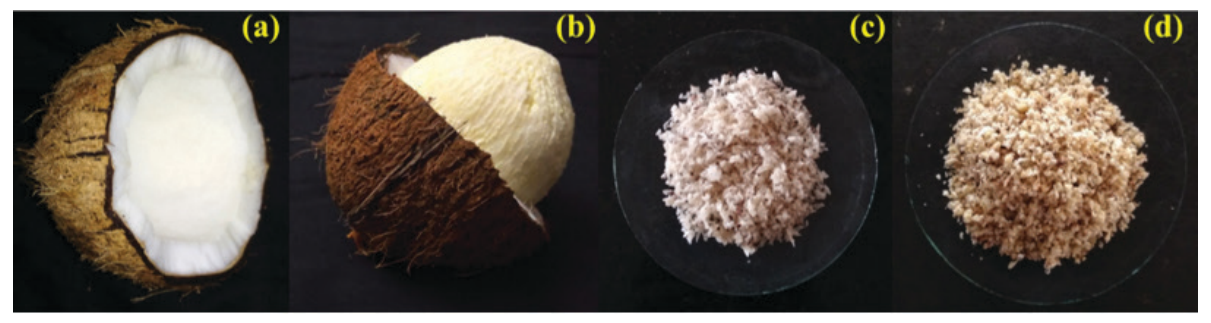

Figure 1: (a) \& (b) Coconut meat and sprout (c) \& (d) Dried powder of coconut meat and its sprouts.

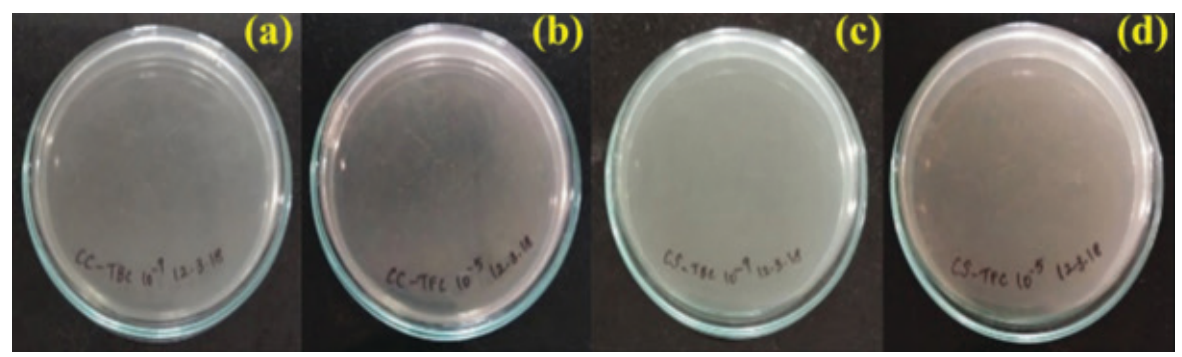

Figure 2: Total Bacterial \& Total Fungal Count (after 6 ${ }^{\text {th }}$ month) (a) \& (b) Coconut meat (c) \& (d) Coconut sprouts. 


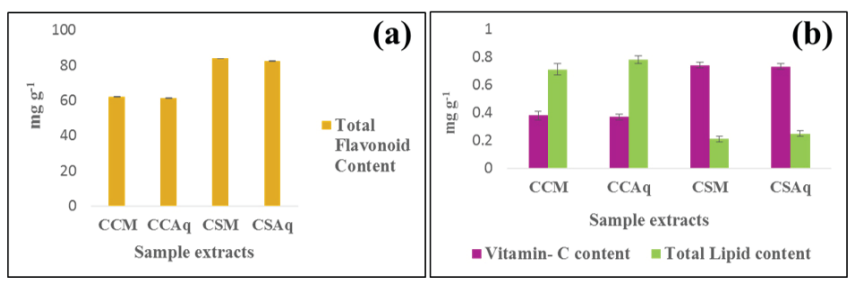

Figure 3: (a) \& (b) Total Flavonoid, vitamin- C, lipid content in the sample extracts.

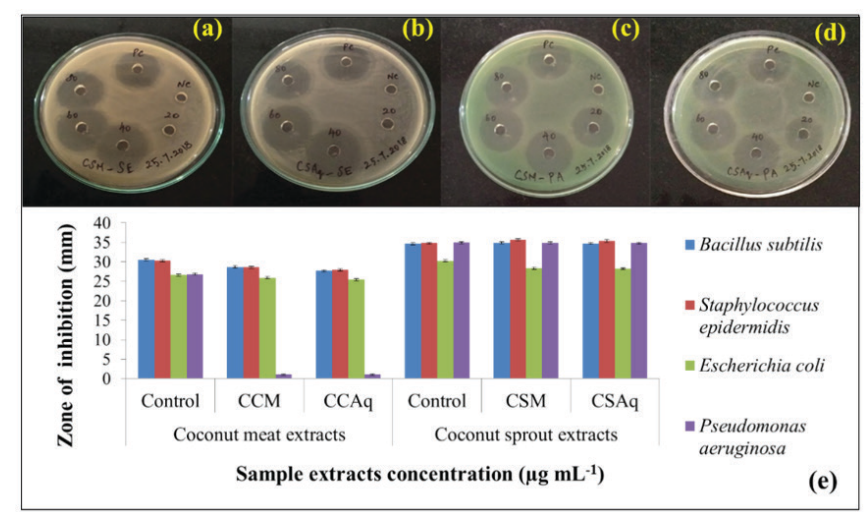

Figure 4: (a) \& (b) Methanol and aqueous sprout extracts against Staphylococcus epidermidis (c) \& (d) Methanol and aqueous sprout extracts against $P$ seudomonas aeruginosa (e) Anti-bacterial activity of the sample extracts.

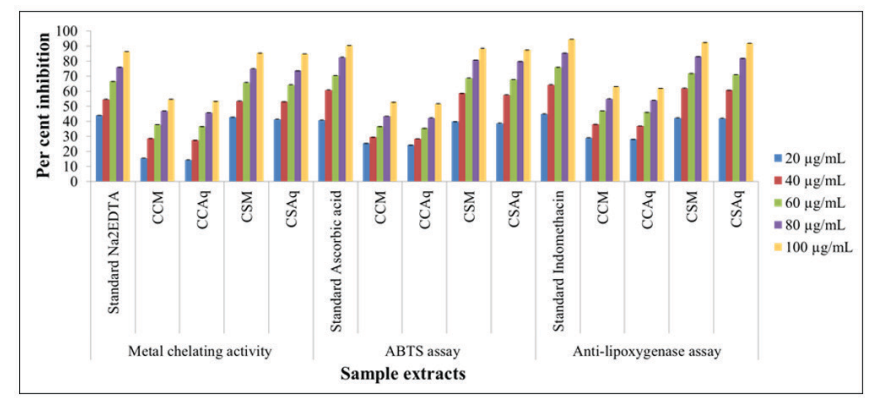

Figure 5: In vitro antioxidant and anti-inflammatory activity of the sample extracts.

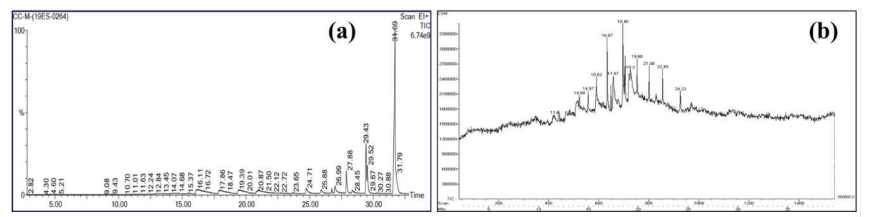

Figure 6: (a) \& (b) GC-MS spectrum of methanol extract of the samples.

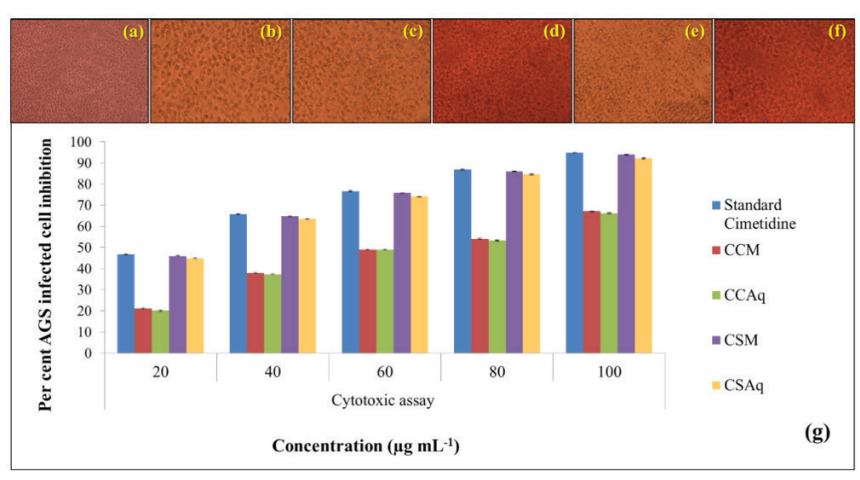

Figure 7: Illustration of cytotoxic activity (a) Control (b) Standard (c) \& (d) Methanol and aqueous coconut meat extract (e) \& (f) Methanol and aqueous coconut sprouts extract (g) Cytotoxic MTT assay of the sample extracts. 